\title{
Effect of gestational thrombocytopenia on negative fetal and maternal outcomes in low-risk pregnancies
}

\section{Düşülk riskli gebelerde gestasyonel trombositopeni"nin negatif fetal ve maternal sonuçlar üzerine etkisi}

\author{
Mefkure Eraslan Șahin ${ }^{1}$, Erdem Șahinn ${ }^{1}$, Yusuf Madendağ ${ }^{2}$, İlknur Cöl Madendag ${ }^{3}$, Gökhan Açmaz ${ }^{2}$
}

${ }^{1}$ Department of Obstetrics and Gynecology, Sivas Sarkışla Government Hospital, Sivas, Turkey

${ }^{2}$ Department of Obstetrics and Gynecology, Erciyes University Medicine Faculty, Kayseri, Turkey

${ }^{3}$ Department of Obstetrics and Gynecology, Health Sciences University Kayseri Education and Research Hospital, Kayseri, Turkey

Corresponding author: Mefkure Eraslan Sahin, MD, Department of Obstetrics and Gynecology, Sivas Sarkışla Government Hospital, Sivas, Turkey

E-mail: mefkureee@hotmail.com

Received/Accepted: October27, 2018 /September 26, 2019

Conflict of interest: There is not a conflict of interest.

\section{SUMMARY}

Objective: Thrombocytopenia, expressed as platelet counts lower than 150 $\times 10^{9} / \mathrm{L}$, is a common hematological anomaly seen in $6.6 \%$ of the pregnancies. Incidental thrombocytopenia of the pregnancy, commonly referred to as gestational thrombocytopenia, accounts for $70 \%-80 \%$ of cases.

This study aimed to elucidate the effect of gestational thrombocytopenia on negative fetal and maternal results in low-risk pregnancies.

Method: The patients were divided into two groups. The control group ( $n$ $=240$ ) consisted of healthy pregnant women with normal platelet count, and the study group $(n=80)$ consisted of pregnant women with gestational thrombocytopenia.

Results: Maternal age, pre-pregnancy body mass indexes, parity, and previous cesarean history rates were similar in both groups. Gestational age during delivery, fetal weight, delivery induction, amniotic fluid stained with meconium, hyperbilirubinemia, admission to neonatal intensive care unit, transient tachypnea of the newborn, respiratory distress syndrome, hypoxicischemic encephalopathy, necrotizing enterocolitis, intraventricular hemorrhage, and 5-min Apgar scores of $<7$ were not different between the groups $(P=0.056, P=0.233, P=0.582, P=0.798, P=0.711, P=0.859$, $P=0.634, P=1, P=1, P=1, P=1$, and $P=1$, respectively). Spontaneous vaginal delivery, necessity for emergency cesarean delivery, postpartum hemorrhage, abnormal hemorrhage during cesarean, necessity for blood transfusion, and postpartum hysterectomy rates did not differ between the groups $(P=0.530, P=0.752, P<0.001, P<0.001, P=0.758, P=1, P=$ 1 , and $P=1$, respectively). Despite being within normal limits, discharge time after $\mathrm{C} / \mathrm{S}$ and spontaneous vaginal delivery was longer in the gestational thrombocytopenia group than in the control group.

Conclusions: The results of the study showed that gestational thrombocytopenia did not pose a risk for both the mother and the fetus in low-risk pregnancies.

Keywords: Gestational thrombocytopenia, negative fetal outcome, negative maternal outcome, term pregnancy

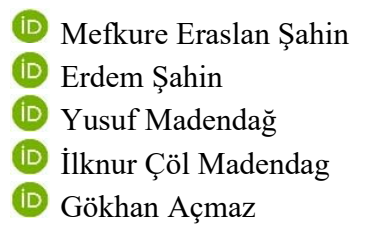

ORCID IDs of the authors: M.E.Ş. 0000-0001-6484-9132 E.Ş. 0000-0001-9492-6223 Y.M. 0000-0002-7622-2991 İ.Ç.M. 0000-0001-6700-2236 G.A. $0000-0002-4215-3676$ 


\section{ÖZET}

Amaç: Trombositopeni gebeliklerin \%6,6'sında görülen en sık hematolojik anomali olup, trombosit sayısnın $150 \times 10^{9}$ /L 'nin altında olması olarak ifade edilir. Gestasyonel trombositopeni olarak da ifade edilen gebeliğin incidental trombositopenisi olguların \%70-80'ini oluşturur.

$\mathrm{Bu}$ çalışma, gestasyonel trombositopeninin düşük riskli gebeliklerde negatif fetal ve maternal sonuçlara etkisini açıklığa kavușturmayı amaçlamıștır.

Yöntem: Hastalar iki gruba ayrıldı. Kontrol grubu $(\mathrm{n}=240)$ normal trombosit sayısı olan sağlıklı gebe kadınlardan oluşmaktaydı ve çalışma grubu $(\mathrm{n}=80)$ gestasyonel trombositopenili gebe kadınlardan oluşuyordu.

Bulgular: Maternal yaş, gebelik öncesi vücut kitle indeksi, parite ve önceki sezaryen öyküsü oranları her iki grupta benzerdi. Doğum sırasında gebelik yaşı, fetal ağırlık, doğum indüksiyonu, mekonyum ile boyanmış amniyotik sıvı, hiperbilirubinemi, yenidoğan yoğun bakım ünitesine giriş, yenidoğanın geçici takipne, solunum sıkıntısı sendromu, hipoksik-iskemik ensefalopati, nekrotizan enterokolit, intraventriküler kanama ve 5 dakika Apgar skorları $<7$ olması gruplar arasında farklı değildi $(\mathrm{P}=0.056, \mathrm{P}=0.233, \mathrm{P}=0.582, \mathrm{P}=0.798, \mathrm{P}=0.711, \mathrm{P}=0.859, \mathrm{P}=0.634, \mathrm{P}=1, \mathrm{P}=1$, $\mathrm{P}) .=1, \mathrm{P}=1$, ve $\mathrm{P}=1$, sirasıyla). Spontan vajinal doğum, acil sezaryen doğumunun gerekliliği, postpartum kanama, sezaryen sırasında anormal kanama, kan transfüzyonu gerekliliği ve postpartum histerektomi oranları gruplar arasında farklilık göstermedi ( $\mathrm{P}=0.530, \mathrm{P}=0.752, \mathrm{P}<0.001, \mathrm{P}<0.001, \mathrm{P}=0.758, \mathrm{P}=1, \mathrm{P}=1$ ve $\mathrm{P}=1$, sirasiyla). Normal sınırlarda olmasına rağmen, sezeryan ve spontan vajinal doğum sonrası taburculuk süresi gestasyonel trombositopeni grubunda kontrol grubuna göre daha uzundu.

Sonuç: Çalışmanın sonuçları, gestasyonel trombositopeninin düşük riskli gebelerde hem anne hem de fetus için risk oluşturmadığını gösterdi.

Anahtar sözcükler: Gestasyonel trombositopeni, negatif fetal sonuç, negatif maternal sonuç, term gebelik

\section{INTRODUCTION}

Thrombocytopenia, expressed as a platelet count of less than $150 \times 10^{9} / \mathrm{L}$, is a common hematological abnormality in pregnancy with an incidence of $6.6 \%{ }^{1} \quad$ Incidental thrombocytopenia of the pregnancy, commonly referred to as gestational thrombocytopenia, accounts for $70 \%-80 \%$ of cases ${ }^{1}$. The pathogenesis of the abnormality is uncertain, but the causes of gestational thrombocytopenia may be a number of medical conditions such as hemodilution and increased destruction $^{2}$. Gestational thrombocytopenia has several characteristics ${ }^{3}$. The first one of these is the appearance between the middle of the second trimester and the third trimester. In most of these cases, the platelet count is higher than $75 \times 10^{9}$ $/ \mathrm{L}^{4,5}$. The second is that women with gestational thrombocytopenia are asymptomatic and have no hemorrhage history. The third is that the women had no thrombocytopenia history except during pregnancy. The fourth is that the number of platelets usually returns to normal in 1-2 months after postpartum ${ }^{6}$.

Thrombocytopenia is classified as mild when the platelet count is in the $100-150 \times 10^{9} / \mathrm{L}$ range, moderate when it is in the $50-100 \times 10^{9} / \mathrm{L}$ range, and severe when it is lower than $50 \times 10^{9} / \mathrm{L}$. Mild thrombocytopenia is the most common platelet disorder during pregnancy. Moderate and severe thrombocytopenia is observed in only $1 \%$ of pregnant women ${ }^{5}$. Severe thrombocytopenia during pregnancy increases the risk of postpartum hemorrhage, neonatal asphyxia, and neonatal thrombocytopenia ${ }^{7}$.

In current clinical practice, gestational thrombocytopenia remains a source of concern for both the mother and the obstetrician, although negative maternal and fetal outcomes occur in the presence of severe thrombocytopenia. Thus, this study aimed to clarify the effect of gestational thrombocytopenia on negative fetal and maternal outcomes in low-risk pregnancies.

\section{MATERIAL AND METHODS}

This retrospective study was conducted by scanning the results of the pregnant women matching the criteria of the study between January 2016 and June 2018. It included pregnant women aged 18-35 years having singleton gestation, who gave birth in Sivas Sarkisla Government Hospital and whose platelet counts were at the level of 75$150 \times 10^{9} / \mathrm{L}$ in their full blood count during 37-41 weeks of pregnancy. This study was approved by the ethics committee of the Cumhuriyet University on the basis of the Helsinki Declaration (approval number: 2018-05/18).

Patients with multiple pregnancies, gestational diabetes, type 1 and type 2 diabetes, preeclampsia, gestational hypertension, chronic hypertension, presence of a fetal anomaly, presence of a chromosome anomaly, smoking, and alcohol use, and chronic liver, kidney, and heart diseases were excluded from the study. 
In addition, patients having a history of HELLP (hemolysis $(\mathrm{H})$, elevated liver enzymes (EL) and low platelet count (LP)) syndrome, primary immune thrombocytopenia, antiphospholipid antibody syndrome, systemic lupus syndrome, human immunodeficiency virus (HIV), hepatitis C, cytomegalovirus, Helicobacter pylori, disseminated intravascular coagulopathy, thrombotic thrombocytopenia, hemolytic uremic syndrome, bone marrow diseases, nutritional deficiencies, and congenital thrombocytopenia that might cause thrombocytopenia in pregnancy were excluded from the study ${ }^{8}$.

The patients were divided into two groups. The control group $(n=240)$ consisted of healthy pregnant women with normal platelet count, and the study group $(n=80)$ consisted of pregnant women with gestational thrombocytopenia.

The cases having platelet counts in the range 75$150 \times 10^{9} / \mathrm{L}$ were determined as gestational thrombocytopenia, and other factors leading to thrombocytopenia during pregnancy were excluded during this identification.

Demographic data such as age, gravida, parity, body mass index $\left(\mathrm{kg} / \mathrm{m}^{2}\right)$, and previous cesarean history were recorded. Negative perinatal outcomes were defined as the presence of any of the following: 5-min Apgar $<7$, transient tachypnea of the newborn (TTN), respiratory distress syndrome (RDS), amniotic fluid stained with meconium, admission to neonatal intensive care unit (NICU), hyperbilirubinemia, hypoxicischemic encephalopathy (HIE), intraventricular hemorrhage (IVH), and neonatal death'. Postpartum hemorrhage was defined as $>500 \mathrm{~mL}$ blood loss at vaginal birth and $>1000 \mathrm{~mL}$ at cesarean delivery ${ }^{10}$.

The Minitab16 statistical software was used to perform statistical analysis (Minitab Inc., PA, USA). The Shapiro-Wilk test was used to assess the normality of the data, and the Levene test was used to assess the homogeneity of the variances. Values were expressed as mean \pm standard deviation. Parametric comparisons were made using the $t$-test or $z$ test. Nonparametric comparisons were made using the Mann-Whitney $U$ test. A $P$ value $<0.05$ was considered significant.

\section{RESULTS}

Of the 320 pregnant women included in the study, 80 belonged to the gestational thrombocytopenia group, and 240 belonged to the control group. Table 1 shows the comparisons of demographic and obstetric characteristics. Maternal age $(P=$ $0.322)$, pre-pregnancy BMI $(P=0.057)$, gravida $(P$ $=0.799)$, parity $(P=0.979)$, and previous cesarean delivery rates $(P=0.662)$ were similar in both groups.

Table 1: Comparison of demographic and obstetric characteristics

\begin{tabular}{|l|c|c|c|}
\hline & $\begin{array}{c}\text { Gestational } \\
\text { thrombocytopenia group } \\
(\mathbf{n = 8 0 )}\end{array}$ & Control group $(\mathbf{n}=\mathbf{2 4 0})$ & P value \\
\hline Maternal age (year) & $29.2 \pm 3.6$ & $28.8 \pm 3.76$ & 0.322 \\
\hline Gravidity & $3 \pm 1.1$ & $2.9 \pm 1.1$ & 0.799 \\
\hline Parity & $1.9 \pm 1.1$ & $1.9 \pm 1.0$ & 0.979 \\
\hline Pregnancy BMI $\left(\mathrm{kg} / \mathrm{m}^{2}\right)$ & $26.01 \pm 2.25$ & $25.40 \pm 2.41$ & 0.057 \\
\hline $\begin{array}{l}\text { Previous C-section history, } n \\
(\%)\end{array}$ & $23(28.7 \%)$ & $63(26.25 \%)$ & 0.662 \\
\hline
\end{tabular}

Table 2 shows the fetal results. The gestational age at delivery, fetal weight, delivery induction, amniotic fluid stained with meconium, hyperbilirubinemia, NICU admission, TTN, RDS, HIE, NEC, IVH, 5-min Apgar scores of $<7$, and neonatal death results were not significantly different between the groups $(P=0.056, P=0.233$, $P=0.582, P=0.798, P=0.711, P=0.859, P=$ $0.634, P=1, P=1, P=1, P=1$, and $P=1$, respectively). 
Table 2: Comparison of fetal outcomes between groups

\begin{tabular}{|l|c|c|c|}
\hline & $\begin{array}{c}\text { Gestational } \\
\text { thrombocytopenia group } \\
(\mathbf{n = 8 0 )}\end{array}$ & Control group (n= 240) & P value \\
\hline $\begin{array}{l}\text { Gestational age at delivery } \\
\text { (week) }\end{array}$ & $39.3 \pm 1.2$ & $38.8 \pm 1.1$ & 0.056 \\
\hline Fetal weight (g) & $3080 \pm 240$ & $3140 \pm 310$ & 0.233 \\
\hline Induction of labor, $n(\%)$ & $28(35 \%)$ & $77(32 \%)$ & 0.582 \\
\hline $\begin{array}{l}\text { Meconium-stained amniotic } \\
\text { fluid, } n(\%)\end{array}$ & $6(7.5 \%)$ & $16(6.6 \%)$ & 0.798 \\
\hline Hyperbilirubinemia, $n(\%)$ & $3(3.75 \%)$ & $7(2.9 \%)$ & 0.711 \\
\hline Admission to NICU, $n(\%)$ & $3(3.75 \%)$ & $8(3.3 \%)$ & 0.859 \\
\hline 5 -min Apgar $<7, n(\%)$ & $0(0 \%)$ & $0(0 \%)$ & 1 \\
\hline RDS, $n(\%)$ & $0(0 \%)$ & $0(0 \%)$ & 1 \\
\hline TTN, $n(\%)$ & $1(1.25 \%)$ & $5(2 \%)$ & 0.634 \\
\hline NEC, $n(\%)$ & $0(0 \%)$ & $0(0 \%)$ & 1 \\
\hline IVH, $n(\%)$ & $0(0 \%)$ & $0(0 \%)$ & 1 \\
\hline Neonatal death, $n(\%)$ & $0(0 \%)$ & $0(0 \%)$ & 1 \\
\hline
\end{tabular}

Table 3 shows the maternal results. Spontaneous vaginal delivery, emergency cesarean section necessity, postpartum hemorrhage, abnormal hemorrhage during cesarean section, necessity for blood transfusion, and postpartum hysterectomy were not significantly different between the groups
$(P=0.530, P=0.752, P<0.001, P<0.001, P=$ $0.758, P=1, P=1$, and $P=1$, respectively). Despite being within normal limits, discharge time after cesarean and spontaneous vaginal delivery was longer in the gestational thrombocytopenia group than in the control group.

Table 3: Comparison of maternal outcomes between groups

\begin{tabular}{|l|c|c|c|}
\hline & $\begin{array}{c}\text { Gestational } \\
\text { thrombocytopenia group } \\
(\mathbf{n = 8 0 )}\end{array}$ & Control group (n= 240) & Pvalue \\
\hline $\begin{array}{l}\text { Spontaneous vaginal } \\
\text { delivery, } n \text { (\%) }\end{array}$ & $54(67.5 \%)$ & $169(70.4 \%)$ & 0.530 \\
\hline $\begin{array}{l}\text { Urgent cesarean delivery, } n \\
(\%)\end{array}$ & $4(5 \%)$ & $10(4.14 \%)$ & 0.752 \\
\hline $\begin{array}{l}\text { Discharge from hospital after } \\
\text { cesarean section (h) }\end{array}$ & $49.15 \pm 2.56$ & $47.88 \pm 2.29$ & $<0.001$ \\
\hline $\begin{array}{l}\text { Discharge from hospital after } \\
\text { vaginal delivery (h) }\end{array}$ & $25.05 \pm 1.18$ & $23.21 \pm 2.18$ & $<0.001$ \\
\hline Postpartum bleeding, $n(\%)$ & $1(1.25 \%)$ & $2(0.8 \%)$ & 0.758 \\
\hline $\begin{array}{l}\text { Abnormal bleeding during } \\
\text { cesarean section, } n(\%)\end{array}$ & $0(0 \%)$ & $0(0 \%)$ & 1 \\
\hline $\begin{array}{l}\text { Blood transfusion } \\
\text { requirement, } n(\%)\end{array}$ & $0(0 \%)$ & $0(0 \%)$ & 1 \\
\hline $\begin{array}{l}\text { Postpartum hysterectomy, } n \\
(\%)\end{array}$ & $0(0 \%)$ & $0(0 \%)$ & \\
\hline
\end{tabular}




\section{DISCUSSION}

This study aimed to elucidate the effect of gestational thrombocytopenia on negative fetal and maternal outcomes in low-risk pregnancies. The results showed that gestational thrombocytopenia did not increase the risk of negative perinatal outcomes for both the mother and the fetus in lowrisk pregnancies.

Clinicians often face thrombocytopenic pregnancies in a routine clinical examination. Clinicians can effectively manage thrombocytopenic pregnancies if the cause of the disease is diagnosed before delivery or during delivery, but a definitive thrombocytopenia diagnosis for many obstetric patients is only performed after delivery. This creates a challenge for clinicians in designing a safe plan for delivery. The presence or absence of an underlying disease that causes or accompanies thrombocytopenia at this point is the main determinant of maternal and fetal outcomes.

The results of this study showed that gestational thrombocytopenia is not a risk factor for negative fetal and maternal outcomes. These positive results could be explained by the absence of risk factors or diseases that affect platelet function and counting. Various studies in the literature have evaluated gestational thrombocytopenia and its effects on the mother and fetus. Similarly, a prospective cohort study performed by Burrows and Kelton on 756 females showed that gestational thrombocytopenia was not associated with any hemorrhage complications ${ }^{1}$. In another study, Levy and Murphy found that mild gestational thrombocytopenia had no negative effects on the fetus, newborn, and mother $^{11}$. In a recently published study, YingHsven Lin et al. reported that incidental thrombocytopenia in low-risk pregnancies is not an increased risk factor for negative perinatal outcomes during delivery ${ }^{10}$. Finally, in 2016, the ACOG study bulletin reported that women with gestational thrombocytopenia did not pose a risk for maternal or fetal hemorrhage or bleeding complications ${ }^{8}$.

In the birth statistics of Turkey, it is reported that $1,291,055$ live births occurred in $2017^{12}$. When the incidence rate of gestational thrombocytopenia $(6.6 \%)$ is considered, approximately 85,000 gestational thrombocytopenia cases per year are encountered in Turkey. When the clinicians consult these patients, they can tell the patient and her family that no risk exists for the mother and the baby, vaginal delivery and cesarean operations can be performed safely, and they should not be concerned about this situation.

\section{CONCLUSION}

The findings of this study indicated that gestation thrombocytopenia did not increase the risk of a negative perinatal outcome for both the mother and the fetus in low-risk pregnancies.

\section{REFERENCES}

1. Burrows RF, Kelton JG. Fetal thrombocytopenia and its relation to maternal thrombocytopenia. $\mathrm{N}$ Engl J Med. 1993;329(20):1463-6.

2. Provan D, Stasi R, Newland AC, Blanchette VS, Bolton-Maggs P, Bussel JB, et al. International consensus report on the investigation and management of primary immune thrombocytopenia. Blood. 2010;115(2):168-86.

3. Gernsheimer T, James AH, Stasi R. How I treat thrombocytopenia in pregnancy. Blood. 2013;121(1):38-47.

4. Boehlen F, Hohlfeld P, Extermann P, Perneger $\mathrm{TV}$, de Moerloose P. Platelet count at term pregnancy: a reappraisal of the threshold. Obstetrics and gynecology. 2000;95(1):29-33.

5. Sainio S, Kekomaki R, Riikonen S, Teramo K. Maternal thrombocytopenia at term: a populationbased study. Acta obstetricia et gynecologica Scandinavica. 2000;79(9):744-9.

6. Ruggeri M, Schiavotto C, Castaman G, Tosetto A, Rodeghiero F. Gestational thrombocytopenia: a prospective study. Haematologica. 1997;82(3):341-2.

7. Wang X, Xu Y, Luo W, Feng H, Luo Y, Wang $\mathrm{Y}$, et al. Thrombocytopenia in pregnancy with different diagnoses: Differential clinical features, treatments, and outcomes. Medicine. 2017;96(29):e7561.

8. American College of $\mathrm{O}$, Gynecologists' Committee on Practice B-O. Practice Bulletin No. 166: Thrombocytopenia in Pregnancy. Obstetrics and gynecology. 2016;128(3):e43-53.

9. Sahin E, Madendag Y, Tayyar AT, Sahin ME, Col Madendag I, Acmaz G, et al. Perinatal outcomes in uncomplicated late preterm pregnancies with borderline oligohydramnios. J Matern Fetal Neonatal Med. 2017:1-4.

10. Lin YH, Lo LM, Hsieh CC, Chiu TH, Hsieh TT, Hung TH. Perinatal outcome in normal pregnant women with incidental thrombocytopenia at delivery. Taiwan J Obstet Gynecol. 2013;52(3):347-50. 
11. Levy JA, Murphy LD. Thrombocytopenia in pregnancy. The Journal of the American Board of Family Practice. 2002;15(4):290-7.
12.

http://www.tuik.gov.tr/PreHaberBultenleri.do?id= 27588 